(c) 2007 Elsevier B.V. All rights reserved.

\title{
High resolution seafloor images in the Gulf of Cadiz, lberian margin
}

\author{
V. Hanquiez ${ }^{1,{ }^{*}}$, T. Mulder ${ }^{1}$, P. Lecroart ${ }^{1}$, E. Gonthier ${ }^{1}$, E. Marchès ${ }^{1}$, M. $_{\text {Voisset }}{ }^{2}$ \\ ${ }^{1}$ Université Bordeaux 1; CNRS; UMR 5805-EPOC, avenue des facultés Talence, 33405 France. \\ ${ }^{2}$ IFREMER; Département Géosciences Marines, BP 70, Plouzané, 29280 France. \\ *: Corresponding author : Hanquiez V., email address : v.hanquiez@epoc.u-bordeaux1.fr, Tel: 335400034 \\ 35. Fax: 335568840848.
}

\begin{abstract}
:
In the Gulf of Cadiz, the hydrodynamic process acting on particle transport and deposition is a strong density-driven bottom current caused by the outflow of the saline deep Mediterranean water at the Strait of Gibraltar: the Mediterranean Outflow Water (MOW). New high resolution acoustic data including EM300 multibeam echo-sounder, deep-towed acoustic system SAR and very high resolution seismic, completed by piston cores collected during the CADISAR cruise allow to improve the understanding of the hydrodynamics of the MOW in the eastern part of the Gulf of Cadiz. Interpretation of data corrects the previous model established in this area and allows, for the first time, the accurate characterization of various bedforms and erosive structures along the MOW pathway and the precise identification of numerous gravity instabilities. The interaction between the MOW, the seafloor morphology and the Coriolis force is presently the driving force of the sedimentary distribution pattern observed on the Gulf of Cadiz continental slope.
\end{abstract}

Keywords: Gulf of Cadiz; Mediterranean Outflow Water (MOW); Contourites; deep-towed SAR; acoustic facies; sedimentary processes; instabilities 


\section{INTRODUCTION}

The Gulf of Cadiz is located between the Strait of Gibraltar (Spain) and the Cape St Vincent (Portugal). The Gulf is placed at the Eurasian and African plate boundary and subjected to complex tectonic processes (Srivastava et al., 1990; Sartori et al., 1994; Maldonado and Nelson, 1999). This tectonic activity is partly responsible for the formation of the diapiric ridges diverting the Mediterranean Outflow Water (MOW) pathway since the Quaternary (Nelson et al., 1993; Llave et al., 2007).

Present day water circulation along the Gulf of Cadiz margin is controlled by the exchanges between the Atlantic Inflow surface current circulating as deep as $300 \mathrm{~m}$ (Mélières, 1974), and the MOW bottom current flowing between 300 and 1500 m water depth (Madelain, 1970; Ambar et al., 1999) (Figure 1). The MOW flows westward just west of the strait of Gibraltar with a velocity reaching 2.5 m s-1 (Boyum, 1967; Madelain, 1970; Ambar and Howe, 1979). West of $6^{\circ} 20^{\prime} \mathrm{W}$, the MOW is deflected northward and splits into two cores (Madelain, 1970; Zenk, 1975; Ambar and Howe,1979; Gardner and Kidd, 1983; Ochoa and Bray, 1991; Johnson and Stevens, 2000; Borenäs et al., 2002; García, 2002; Hernández-Molina et al., 2003): (1) the Mediterranean Upper Water (MUW, Figure 1), a geostrophic current following a northerly path between 300 and $600 \mathrm{~m}$ water depth (Ambar and Howe, 1979; Ambar et al., 1999; Baringer and Price, 1999), and (2) the Mediterranean Lower Water (MLW, Figure 1), an ageostrophic current flowing westwardly from the Strait of Gibraltar, at water depths ranging from 600 to 1500 m (Madelain, 1970; Zenk and Armi, 1990; Baringer, 1993; Bower et al., 1997). At about $7^{\circ} \mathrm{W}$, the MLW splits into three branches (Intermediate/IMB, Principal/PMB and Southern/SMB; Madelain, 1970; Kenyon and 
Belderson, 1973; Mélières, 1974; Nelson et al., 1993; García, 2002), due to a complex

bathymetry (Figure 2) previously described by Mulder et al. (2003) and HernándezMolina et al. (2003, 2006). According to the distribution of Hernández-Molina et al. (2003), three morpho-sedimentary sectors are distinguished in this area:

(1) The proximal scour and sand-ribbons sector with the Main MOW Channel (MMC, Figure 2) which drains the MUW and the MLW.

(2) The channels and ridges sector with (i) the Cadiz Contourite Channel (CC, Figure 2) which drains the SMB, the Huelva Channel (HC, Figure 2) which drains the IMB, and the Guadalquivir Channel (GC, Figure 2) which drains the PMB; (ii) the topographic highs composed of the Cadiz (CR, Figure 2), Doñana (DR, Figure 2), Guadalquivir (GR, Figure 2) diapiric ridges, and the Guadalquivir Bank (GB, Figure 2); (iii) the smooth areas composed of the Bartolome Dias (BDD, Figure 2), Faro-Cadiz (FCD, Figure 2), Guadalquivir (GD, Figure 2) and Huelva (HD, Figure 2) drifts;

(3) The overflow-sedimentary lobe sector recently interpreted as a Giant Contouritic Levee (Mulder et al., 2003) (CL, Figure 2) partly dissected by the Gil Eanes Channel (GEC, Figure 2) and by secondary channels (SC, Figure 2) and whose western part coincide with the ponded basin area (PB, Figure 2).

The MOW disconnects from the seafloor at around $1200 \mathrm{~m}$ and $1500 \mathrm{~m}$ water depth in the eastern and western parts of the Gulf, respectively, and becomes a water mass intercalated between the deep and intermediate Atlantic waters (Baringer and Price, 1999; Hernández-Molina et al., 2003). The MOW velocity decreases gradually down to $0.5 \mathrm{~m} \mathrm{~s}^{-1}$ on the middle slope (Kenyon and Belderson, 1973), and $0.2 \mathrm{~m} \mathrm{~s}^{-1}$ off Cape St Vincent (Meincke et al., 1975; Johnson et al., 2002). The progressive MOW velocity decrease leads to particle sorting and induces varied development of sedimentary bodies along its path. In the most proximal part of Gibraltar, the main deposits are coarsegrained sediments with giant furrows, ribbons, and sand waves (Kenyon and Belderson, 
1973; Habgood et al., 2003; Mulder et al., 2003) while, downstream, the fine-grained deposits built in silty-clayey contouritic drifts (Gonthier et al., 1984; Faugères et al., 1985a; Stow et al., 1986).

80 Several studies have been focussed on the sedimentary facies and processes on the 81 Gulf of Cadiz continental slope for about forty years (e.g. Heezen and Johnson, 1969; Madelain, 1970; Kenyon and Belderson, 1973; Mélières, 1974; Faugères et al., 1985b; Stow et al., 1986, 2002; Nelson et al., 1993, 1999; Llave et al., 2001, 2006, 2007; Habgood et al., 2003; Hernández-Molina et al., 2003, 2006). Heezen and Johnson (1969) and Kenyon and Belderson (1973) would be the first to identify, from bottom photographs and sidescan sonar images, several provinces characterized by distinct sedimentary features in the middle slope of the Gulf of Cadiz. Save for few modifications introduced to this classification during the nineties, since 2000, more

89 detailed analysis of the slope morphology and the MOW variability, with the identification of new provinces, has become possible using modern acoustic systems (Habgood et al., 2003; Hernández-Molina et al., 2003, 2006; Mulder et al., 2003; Llave et al., 2007 among the more recent studies). Compared to the resolution of these previous acoustic systems (e.g. EM12S-120 multibeam echo-sounder, Seamap and

94 TOBI sidescan sonars), the accuracy of our acoustic data (EM300 and SAR imagery spatial resolution equal to $12.5 \mathrm{~m}$ and $0.25 \mathrm{~m}$, respectively) allows, for the first time, a very high resolution characterisation of the seafloor at a regional scale. In this paper, we

97 present a new distribution pattern of the sediments in the eastern part of the Gulf of 98 Cadiz where numerous gravity instabilities are identified, and the close connection 99 between the MOW, the Coriolis force and the seafloor morphology is demonstrated. 


\section{MATERIAL AND METHODS}

102 The data presented in this paper were collected during the CADISAR Cruise on the

103 RV 'Le Suroît' in August 2001. Bathymetric (Figure 2) and acoustic imagery (Figure 3)

104 data were acquired with a SIMRAD EM300 multibeam echosounder, system operating

105 at a $32 \mathrm{kHz}$ frequency. The spatial and vertical bathymetry resolution is $30 \mathrm{~m} \times 30 \mathrm{~m}$

106 and $2 \mathrm{~m}$, respectively. The imagery spatial resolution is $12.5 \mathrm{~m}$. On the basis of the

107 variations in the backscatter values, interpretation of the acoustic imagery allows to lead

108 to the distribution of the sedimentary facies in the eastern part of the Gulf of Cadiz.

109 EM300 imagery was completed by SAR (Système Acoustique Remorqué) imagery

110 (Figure 3), a deep-towed multisensor geophysical tool (Farcy and Voisset, 1985). It is

111 tracked at $100 \mathrm{~m}$ above the seafloor and works at a $180 \mathrm{kHz}$ frequency. This system,

112 used to calibrate the multibeam imagery, allows to acquire very high resolution data

113 with a sidescan imagery resolution of $0.25 \mathrm{~m}$ and so to accede to the detail morphology

114 of the submarine sedimentary features subjected to the MOW activity. Seismic profiles

115 were acquired from very high resolution sub-bottom profiler operating at a frequency

116 ranging between 2.5 and $3.5 \mathrm{kHz}$ (CHIRP mode). Based on the classification of Damuth

117 and Hayes (1977), which is widely used for classifying deep-ocean sediments using 3.5

$118 \mathrm{kHz}$ echograms, the detailed mapping of the acoustic echofacies in the Gulf of Cadiz

119 from Hanquiez et al. (accepted) is also used. The top of 25 piston cores (Figure 3) were

120 also used to reveal the sediment grain size and to interpret the acoustic imagery.

121 To quantify the circulation of the MOW in the Gulf of Cadiz, we estimated transport

122 flow velocity parameters. However, the relationship between the particle grain size and

123 current velocities is complex: it depends on the cohesion of the sediments and the

124 possibility for each grain to be transported as a discrete particle, either by bed-load, or

125 in suspension in the nepheloid layer. Current velocities are very fluctuating because of

126 turbulence, the particles are not transported continuously in time (Migeon, 2000). The 
127 method we used was proposed by McCave (1984) and consists in evaluating the

128 shearing velocity $\left(U^{x}\right.$ in $\left.\mathrm{cm} \mathrm{s}^{-1}\right)$ for particles transport. $U^{x}$ is estimated using the $90^{\text {th }}$

129 centile (D90) obtained by the granulometric analysis (Table 1). Assumption is made that

130 coarse-grained particles $(>100 \mu \mathrm{m})$ are not transported in suspension but only by bed

131 load. $U^{x}$ is converted into mean transport velocity at $1 \mathrm{~m}$ above the seafloor $(U$ in

$132 \mathrm{~cm} \mathrm{~s}^{-1}$, Table 1) from the experimental relationship (Sternberg, 1968):

$133 U=\sqrt{U^{x 2} / C_{100}}$ where $C_{100}$ is the drag coefficient determined at $3.1 \times 10^{-3}$ by

134 Sternberg.

3. MORPHO-SEDIMENTARY FACIES

137

\subsection{Erosive facies (rocky facies)}

138 The rocky facies is characterized by high "backscatter values" with medium to low

139 backscatter lineaments of about fifty meters wide and 1 to $15 \mathrm{~km}$ long similar to the

140 lineaments and the longitudinal furrows observed on the northern Aquitaine shelf (Cirac

141 et al., 1998) and on the Mont-Saint-Michel Bay (Ehrhold et al., 2003) (Table 2). This

142 facies shows a prolonged bottom echo with no reflector below seafloor, and locally

143 some large and irregular overlapping or single hyperbolae with widely varying vertex

144 elevations above the seafloor. This echo shows similarities with echo types IIB and IIIA

145 of Damuth and Hayes (1977). According to the observation of López-Galindo et al.

146 (1999), Nelson et al. (1999) and Habgood et al. (2003) in the Gulf of Cadiz, this facies

147 is subdivided into a gravely rock and sandy rock facies, both characterized by

148 longitudinal furrows possibly filled by coarse material.

149 


\subsection{Depositional facies}

\subsubsection{Sand sheets}

The sand sheet facies presents a homogeneous low "backscatter values" without apparent structure (Table 2). It is characterized by a continuous, clear bottom echo with no or rare reflectors below seafloor. This facies shows similarities with echo type IA of Damuth and Hayes (1977) and is interpreted as sediment with an important coarse 156 fraction.

\subsubsection{Sand ribbons}

159 The sand ribbon facies shows alternation of high and low backscatter stripes (Table

160 2). The low backscatter features are up to $10 \mathrm{~km}$ long and $200 \mathrm{~m}$ wide. This facies is

161 characterized by a continuous, clear bottom echo with no reflector below seafloor, like 162 echo type IA of Damuth and Hayes (1977). This facies shows similarities with the 163 banded facies observed and described on continental shelves (e.g., Cirac et al., 1998; 164 Ehrhold et al., 2003; Flemming, 1979). In this area, it corresponds to sand ribbons 165 (Habgood et al., 2003; Mulder et al., 2003) overlying a gravelly substrate which shows 166 up as higher "backscatter values". The high sand content (89\%) of the CADKS02 core 167 collected in this facies is consistent with this interpretation (Table 1).

\subsubsection{Small sand waves}

170 The small sand wave facies shows low "backscatter values" with small straight wavy structures of about 1 to $2 \mathrm{~m}$ high and 100 to $200 \mathrm{~m}$ wavelength similar with the small dunes described on the northern Aquitaine shelf by Cirac et al. (1998) (Table 2). The

173 CADKS01 core collected in this facies shows a high sand content (87\%) in the surficial 174 sediments (Table 2). This facies shows regular and intense overlapping hyperbolae with 
175 vertices approximately tangent to the seafloor. This hyperbolic echoes shows

176 similarities with echo type IIIC of Damuth and Hayes (1977).

179 The sand wave facies is characterized by low "backscatter values" with wavy

180 structures characterized by amplitude and wavelength ranging from 4 to $10 \mathrm{~m}$ and 200

181 to $300 \mathrm{~m}$, respectively (Table 2). The CADKS03 core acquired in this facies shows

182 coarse surface sediments with sand content of $95 \%$ (Table 1). This facies shows regular

183 slightly overlapping hyperbolae with varying vertex elevation above the seafloor. It

184 shows similarities with echo type IIIC of Damuth and Hayes (1977). The wavy

185 structures are similar to the dunes described on the southeast African continental shelf

186 (Flemming, 1979) and in the entrance to the Gironde Estuary (Berné et al., 1993). In

187 this work, asymmetrical morphology is mainly observed with locally barkhanoïde sand 188 wave fields.

191 The interfering sand wave facies shows low "backscatter values" with a dense

192 network of straight wavy structures responsible of an embossed morphology (Table 2).

193 Amplitude and wavelength of these bedforms range from 2 to $5 \mathrm{~m}$ and 100 to $150 \mathrm{~m}$,

194 respectively. This facies, located in the sandy zones described by Madelain (1970) and

195 Habgood et al. (2003), shows regular overlapping hyperbolae with varying vertex

196 elevation above the seafloor very similar to echo type IIIC of Damuth and Hayes 197 (1977). 
200 The homogeneous mud facies shows a homogeneous medium "backscatter values" 201 without apparent structure (Table 2). It is characterized by a continuous and clear 202 bottom echo with continuous, parallel reflectors below seafloor. It shows similarities 203 with echo type IB of Damuth and Hayes (1977). The top of CADKS22 and CADKS23 204 cores acquired in this facies shows sediments mainly composed of silt $(\sim 50 \%)$ with a 205 clayey fraction higher than $30 \%$ (Table 1).

206 On the basis of bathymetric data, another facies similar in their acoustic 207 characteristics to the homogeneous mud facies is defined. This facies is characterized by 208 the presence of large kilometric to multi-kilometric depressions and is interpreted as 209 ponded basin deposits (Prather, 2000).

3.2.7. Mud waves

212 The mud wave facies shows medium "backscatter values" with large undulated wavy

213 structures about $40 \mathrm{~m}$ high with a wavelength of $600 \mathrm{~m}$ (Table 2). It presents a wavy 214 continuous bottom echo without hyperbolae with continuous, parallel reflectors below 215 seafloor showing similarities with the echo type IB of Damuth and Hayes (1977). These

216 structures correspond to the large mud waves already recognized and described by 217 Kenyon and Belderson (1973), Nelson et al. (1993) and Habgood et al. (2003).

\section{3.3. Instability facies}

The sandy instability facies presents heterogeneous "backscatter values" without organized features (Table 2). It shows regular to irregular overlapping hyperbolae with 
varying vertex elevation above the seafloor. This facies shows similarities with echo

224 type IIIC of Damuth and Hayes (1977) and chaotic facies described by Cochonat and 225 Ollier (1987).

\subsubsection{Muddy instabilities}

The muddy instability facies shows low to medium "backscatter values" with numerous multi-hectometric curvilinear structures characterized by low to high

230 "backscatter values" (Table 2). It shows regular to irregular overlapping hyperbolae with varying vertex elevation above the seafloor, like echo type IIIC of Damuth and Hayes (1977). Due to the similarities with the sandy instabilities and the observation previously made by Mulder et al. (2003), this facies is interpreted as failure scars and mass flow deposits. On the basis of backscatter variation and lithologic interpretation of Habgood et al. (2003), two subdivision are defined: (1) the muddy sand instabilities, characterized by low "backscatter values" and a medium to high sand content, and (2) the muddy instabilities, characterized by medium "backscatter values" with a low sand content and a low number of curvilinear structures.

\section{DISTRIBUTION OF THE SEDIMENTARY PROCESSES}

\subsection{Proximal scour and sand-ribbons sector}

The south-eastern part of the Main MOW Channel presents erosive furrows related to intense current activity (Kenyon and Belderson, 1973; Belderson et al., 1982; Turcq, 1984). This sector, also characterized by rock outcrops and gravel, shows evidence of an erosive action of the MOW on the seafloor (Figure 4).

246 North of the NNE/SSW concave trench (Figure 2), the MMC is entirely covered by 247 the sandy facies. The type of sandy facies evolves both northward and westward. On 
section beginning in the gravel sector and ending with the Cadiz Channel and the Giant

249 Contouritic Levee, the observed erosional/depositional bedforms are due to the activity 250 of bottom currents (Heezen et al., 1966; Hollister et al., 1974). We find successively 251 sand ribbons, small sand waves and straight or interfering sand waves (Figures 4 and 5).

252 The sand ribbons and the few furrows, observed close to the rock outcrop and gravel 253 area, indicate a transition zone where both erosion and deposition occur. Orientation of 254 these bedforms $\left(110^{\circ} \mathrm{N}\right.$ and $140^{\circ} \mathrm{N}$, south and north of $36^{\circ} \mathrm{N}$, respectively) shows a 255 progressive northwestward bending in a clockwise direction of the MOW ending around $36^{\circ} 02^{\prime} \mathrm{N} / 6^{\circ} 48^{\prime} \mathrm{W}$ (Figure 4). At this location, disappearance of the furrows coincides with the edification of sand waves. These sand waves show crests orientated $35^{\circ} \mathrm{N}$ to $45^{\circ} \mathrm{N}$ in the central sector of the Main MOW Channel, and $5^{\circ} \mathrm{N}$ close to the Giant

259 Contouritic Levee. This change in crest orientation shows a progressive westward 260 bending in an anticlockwise direction of the MOW. These sand waves can morphologically be associated with the washed-out dunes of Simons and Richardson (1961) and illustrate the predominance of depositional processes and the decrease of the MOW velocity. The bedform morphology indicates a current flowing towards $310^{\circ} \mathrm{N}$.

264 Westward, the higher amplitude of the sand waves indicates a decrease of the MOW velocity, according to the bedform classification of Simons and Richardson (1961).

The interfering sand waves observed in the northern part of the Main MOW Channel indicates bi-directional currents at this location. Orientation of a part of the wave crests (towards $65^{\circ} \mathrm{N}$ ) is consistent with a northwestward direction for the MOW. The orientation of the remaining wave crests (towards $25^{\circ} \mathrm{N}$ ) show a westward MOW component and indicates that the SMB have already an effect on the seafloor before to be channelized by the Cadiz Channel. 


\subsection{Channels and ridges sector}

274

275

276

277

278

280

281

282

283

284

The Cadiz Contourite Channel is characterized by rock outcrops and sandy sediments sometimes with sedimentary structures (Figures 4, 6 and 7). Rock outcrops are mainly located along the Cadiz and Guadalquivir ridges, so locally showing the sediment stratification (Figure 6B). East of $7^{\circ} 30^{\prime} \mathrm{W}$, the channel is dissected by furrows orientated $285^{\circ} \mathrm{N}$ west of the Cadiz Ridge, and $40^{\circ} \mathrm{N}$ to $60^{\circ} \mathrm{N}$ along the Guadalquivir Ridge. From $10^{\circ} \mathrm{N}$ to $20^{\circ} \mathrm{N}$ in the upstream part of the channel and $150^{\circ} \mathrm{N}$ along the Guadalquivir Ridge, the wave crest orientation is about $5^{\circ} \mathrm{N}$ just west of $7^{\circ} 35^{\prime} \mathrm{W}$. Change in orientation of these structures shows the southwestward bending in an anticlockwise direction of the SMB along the upstream part of the Cadiz Contourite Channel, then the northwestward bending in a clockwise direction of the SMB along the downstream part of this channel (Figure 4). A westward decrease of the sand wave amplitude is also observed along the channel pathway. This decrease continues until the complete disappearance of these bedforms at $7^{\circ} 47^{\prime} \mathrm{W}$ (Figure $7 \mathrm{C}$ ). These sand waves are mainly straight crests with the exception of a small barchan field focussed around $36^{\circ} 12^{\prime} \mathrm{N} / 7^{\circ} 45^{\prime} \mathrm{W}$ (Figure $7 \mathrm{~A}$ ). The westward reduction of the bedform amplitude, the lack of dynamic structures in the downstream part of the Cadiz Channel, and the finegrained sediments observed from $7^{\circ} 55^{\prime} \mathrm{W}$ (Figure 4) indicate a westward decrease of the SMB competence and velocity.

The Huelva Contourite Channel has a similar sedimentary facies evolution west of the Cadiz and Guadalquivir diapiric ridge rock outcrops. At the western limit of the ridges, the channel floor exhibits sand facies without bedform, and then homogeneous mud, so displaying the nothwestward decrease of the IMB velocity (Figure 4). Rare furrows orientated $120^{\circ} \mathrm{N}$ observed along the channel course testify of an erosive action of the IMB (Figure 4). 
The Guadalquivir Contourite Channel is mainly characterized by sand deposits in its upstream part (Figure 4). This facies is present in two secondary branches surrounding a muddy area with smooth morphology between $7^{\circ} 25^{\prime} \mathrm{W}$ and $7^{\circ} 40^{\prime} \mathrm{W}$ (Mulder et al., 2003) (Figure 4). In the northern branch, thin furrows orientated $60^{\circ} \mathrm{N}$ to $80^{\circ} \mathrm{N}$ are observed (Figure 8). From $7^{\circ} 35^{\prime} \mathrm{W}$, convergence of these two branches is associated with apparition of rock outcrops along the channel course, so showing an acceleration of the PMB at this location (Figure 4). The $120^{\circ} \mathrm{N}$ orientated furrows observed in the distal part of the Guadalquivir Contourite Channel corroborate this interpretation (Figure 4).

Between the main contourite channels, contourite drifts are mainly characterized by

307 fine-grained deposits without dynamic structures, evidence of dominance of deposit 308 processes and low MOW activity in these areas (Figure 4). Only the south-eastern part 309 of the Huelva drift and the southern part of the Guadalquivir drift have sandy surficial 310 deposits. Muddy instabilities can be observed on the southeastern edge of the Bartolome 311 Dias Drift, just east of the Guadalquivir Bank (Figure 4). These semicircle scars, joined and parallel to the right flank of the Guadalquivir Channel, appear related to gravity mass flows (Embley and Hayes, 1976; Jacobi, 1976; Damuth, 1980).

\subsection{Overflow-sedimentary lobe sector}

This sector, previously described as a mud wave to muddy sand wave area (Kenyon and Belderson, 1973; Nelson et al., 1993, 1999; Habgood et al., 2003) contains numerous instabilities in addition to sedimentary structures (Mulder et al., 2003; Hernández-Molina et al., 2003) (Figure 4). In detail, muddy sand instabilities are mainly observed: (1) along the southern edge of the Cadiz Channel and the western edge of the Main MOW Channel (Figure 9A), (2) on the right levee of the Gil Eanes Channel

322 (Figure 10), (3) along and at the mouth of the secondary channels disconnected to the 
324 of the secondary channels connected to the Main MOW Channel, south of the Gil Eanes

325 Channel (Figure 9C and Figure 11A-B). Muddy instabilities cover the rest of the Giant

326 Contouritic Levee, except in areas around $35^{\circ} 52^{\prime} \mathrm{N} / 7^{\circ} \mathrm{W}$ and $35^{\circ} 52^{\prime} \mathrm{N} / 7^{\circ} 24^{\prime} \mathrm{W}$, which

327 are covered by mud waves with $15^{\circ} \mathrm{N}$ to $30^{\circ} \mathrm{N}$ orientated crests (Figure 4). All these

328 instabilities reflect the dominance of gravity processes on the Giant Contouritic Levee.

329 Orientation and continuity of the sand waves, observed in the western part of the

330 Main MOW Channel, at the end of the southern secondary channels (Figure 11A-B),

331 and along the Gil Eanes Channel (Figure 10), indicate action of the MOW in these

332 channels and the westward bending in an anticlockwise direction of this current over the

333 Giant contouritic Levee. Locally, sand waves are also observed on the edges of the

334 secondary channels and have crests sub-parallel to the channel axis (Figure 9C and

335 Figure 11B). In the Gil Eanes Channel, sand waves are associated with narrow sand-

336 filled furrows ( $25 \mathrm{~m}$ width) and scours, which are concentrated along the outer part of 337 the meanders (Figure 10). From $7^{\circ} 12^{\prime} \mathrm{W}$, the Gil Eanes Channel is floored by sand 338 deposits without bedforms, suggesting a south-westward decrease in flow intensity. The 339 sand sheet developed at its mouth is interpreted as gravity depositional lobes (Habgood 340 et al., 2003) (Figure 4).

\section{5. DisCUSSION}

\section{5.1. Hydrodynamics of the MOW}

344 If it is usual that the sedimentary features commonly associated with bottom currents

345 (e.g. mud waves) are generally oblique to flow direction, in our study, the bedform

346 crests are almost perpendicular to the MOW direction. This statement is confirmed in

347 the channelized areas (Main MOW Channel, Cadiz, Huelva and Guadalquivir contourite

348 channels) where the MOW acts as an unidirectional current. Opposite, in the spilling 
zones like the Giant Contouritic Levee (Mulder et al., 2003), the strong change between

350 the channel and levee slopes and the multidirectional nature of the MOW could explain the oblique direction of the large bedform crests compared to the general MOW flow.

Using the relationship of Sternberg (1968) to estimate the MOW transport velocity values and the orientation of furrows and wave crests displayed in the study area, a semi quantitative model of the MOW velocity evolution is established in the eastern part of the Gulf of Cadiz and shows the northward and westward decrease of the MOW energy (Figure 12). Highest velocities, ranging from 115 to $200 \mathrm{~cm} \mathrm{~s}^{-1}$, are in the south-eastern part of the Main MOW Channel. They are consistent with the velocities previously measured by Heezen and Johnson (1969), Madelain (1970) and Baringer and Price (1999) and are also in agreement with the velocity threshold to generate erosive furrows and sand ribbons (Dyer, 1970; Belderson et al., 1982). Downstream, around the Main MOW and Cadiz channel junction, velocities range from 25 to $70 \mathrm{~cm} \mathrm{~s}^{-1}$ and are of the same order that the values of Ambar and Howe (1979) and Baringer and Price (1999). After our estimations, the central part of the Guadalquivir Channel should be characterized by velocities ranging from 18 to $36 \mathrm{~cm} \mathrm{~s}^{-1}$, and about $14 \mathrm{~cm} \mathrm{~s}^{-1}$ on the outer flank of the Giant Contouritic Levee.

\subsection{Impact of the seafloor and the Coriolis force on the MOW pathway}

Erosion of the SMB and PMB observed along the Cadiz and Guadalquivir channels is related to a reduction of the MOW section near the Cadiz and Guadalquivir ridges and Guadalquivir Bank, around $36^{\circ} 14^{\prime} \mathrm{N} / 7^{\circ} 02^{\prime} \mathrm{W}$ (c1, Figure 2), $36^{\circ} 17^{\prime} \mathrm{N} / 7^{\circ} 20^{\prime} \mathrm{W}$ (c2, Figure 2) and $36^{\circ} 24^{\prime} \mathrm{N} / 7^{\circ} 38^{\prime} \mathrm{W}$ (c3, Figure 2$)$, which induces an increase of the SMB and PMB velocities. In addition, the erosive action of these two branches is emphasized

373 by the Coriolis force which plasters the MOW against these ridges. Change in furrow orientation observed along the Cadiz and Guadalquivir channels shows that the SMB 
and PMB follows the pathway defined by these tectonic highs, thus confirming the previous observations of Nelson et al. (1999) (Figure 12).

The muddy nature of the Faro-Cadiz Drift shows that the IMB stays confined in the Huelva Channel along its path. The presence of fine-grained deposits between $7^{\circ} 08^{\prime} \mathrm{W}$ and $7^{\circ} 10^{\prime} \mathrm{W}$ and sandy sediments west of the Guadalquivir Ridge suggests a decrease and then an increase of the IMB competence because of the reduction of the flowing section at $36^{\circ} 25^{\prime} \mathrm{N} / 7^{\circ} 10^{\prime} \mathrm{W}$ (c4, Figure 2 ). The sandy nature of the southern part of the Faro-Cadiz Drift shows that a part of the IMB circulates westward, due to the proximity of the Guadalquivir ridge. Passed the Guadalquivir Ridge, the IMB remains confined into the Guadalquivir Channel where it forms the PMB. This suggests that the divergence between the IMB and the PMB takes place around $36^{\circ} 21^{\prime} \mathrm{N} / 7^{\circ} 07^{\prime} \mathrm{W}$. Downstream, in the central part of the Guadalquivir Channel, the development of a second sandy area west of the Doñana Ridge shows that this tectonic structure is responsible of the PMB dichotomy.

The sandy nature of the north flank of the Guadalquivir Ridge indicates that a part of the SMB spills over this tectonic high around $7^{\circ} 30^{\prime} \mathrm{W}$. Consequently, the Guadalquivir Drift is partly built by the SMB. This spilling is related both to the inertia of the overall westward oriented SMB between $7^{\circ} 05^{\prime} \mathrm{W}$ and $7^{\circ} 20^{\prime} \mathrm{W}$ and to the Coriolis force which orientates the SMB circulation towards the north. In addition, action of the Coriolis force is visible from $7^{\circ} 35^{\prime} \mathrm{W}$ by the northwestward bending in a clockwise direction of the MOW on reaching the western limit of the Guadalquivir Ridge. This MOW bending is also consistent with the end of the confinement of the SMB in the Cadiz Channel. 


\subsection{Interaction between gravity and contouritic processes}

The presence of rock outcrops and sandy material along the submarine valleys

400 bordering the western flank of the Cadiz and Guadalquivir ridges (Figure 12) indicates 401 an erosive action of the currents channelized in these valleys. These valleys, described as marginal valleys by García (2002) and Hernández-Molina et al. (2003), seem to connect the different MLW branches and to transit sediments from the shelf to the slope in the form of gravity currents.

The numerous failure scars observed on the right levee of the Gil Eanes Channel are related to high sedimentation rate due to the spilling of the channelized MOW (Mulder et al., 2003). This is confirmed downstream by both the splayed shape of the large mud wave field and the mud wave crest orientation that is sub-perpendicular to the channel axis. This associated to the presence of distal sandy lobes suggest many similarities

410 between the Gil Eanes Channel and channels found in deep-sea turbidite systems

411 (Normark, 1978; Walker, 1978; Normark et al., 1993). However, due to the permanent 412 circulation of the MOW, the Gil Eanes Channel is interpreted as a typical channel 413 draining downwelling currents (Faugères et al., 1999; Habgood et al., 2003; Mulder et 414 al., 2003). The presence of the previous mud wave field can also be related to the 415 combined action of the MOW which spills over the Giant Contouritic Levee and is 416 responsible for the numerous failure scars observed in this area (Mulder et al., 2003).

417 This is strengthened by the presence of large mud waves south of the connected secondary channels. Reduction of failure scar number and change from muddy sand to

419 muddy deposits in the central and western parts of the Giant Contouritic Levee suggest 420 the westward decrease of the shearing, velocity and competence of the MOW. Sandy 421 instabilities, presented west of the Main MOW Channel, and muddy instabilities, 422 observed on the southeastern edge of the Bartolome Dias Drift, also testify of the 423 interaction between the MOW and gravity processes. 


\section{CONCLuSion}

426

The new high resolution sedimentary facies distribution proposed in this study completes, details, and corrects the previous models established in the eastern part of the Gulf of Cadiz and allows a better understanding of the processes acting in this system. High quality of the imagery data (EM300 and SAR imagery spatial resolution equal to $12.5 \mathrm{~m}$ and $0.25 \mathrm{~m}$, respectively) allows a precise characterization of the diverse bedforms built by the MOW along its path, and an accurate definition of their spatial limits. Sandy deposits are confined in the whole contouritic channels, the Gil

433 Eanes channel and the secondary channels connected to the Main MOW Channel. Bedform changes, deposit lithology, and estimated MOW transport velocities confirm the northward and westward decrease of the MOW energy and competence. Although most of the previous works reveal the sandy nature of the main MOW channel, our study shows, for the first time, the progressive northward and westward evolution of the bedforms along the Main MOW Channel with erosive furrows, sand ribbons, small sand waves, and symmetrical to interfering sand waves. Our study emphasizes the major role 440 of the seafloor morphology, especially the tectonic highs, which determines the MOW

441 pathway and varies the current intensity. The still erosive action of the MOW south of 442 the Guadalquivir Bank, and the evolution of the deposits along the Cadiz Channel (sand waves, sand sheets, and homogeneous mud) are shown. Moreover, the mud wave and muddy sand wave area described in the previous works corresponds, in reality, to an unstable muddy sand sector where gravity processes and MOW flow interact. Finally, estimation method of the current MOW velocities could be enlarged to the past

447 sedimentation in order to improve the paleoenvironmental reconstructions in an area important for the study of the Atlantic/Mediterranean exchanges. 
The authors thank GENAVIR and the crew of the RV "Le Suroît" for technical assistance during the CADISAR cruise. We gratefully thank anonymous reviewer, M. Rebesco, and the editor for their helpful comments to this manuscript. This is an

UMR/CNRS EPOC 5805 contribution $n^{\circ} 1620$.

\section{REFERENCES}

Ambar, I., Armi, L., Bower, A. and Ferreira, T., 1999. Some aspects of time variability of the Mediterranean Water off south Portugal. Deep Sea Research Part I: Oceanographic Research Papers, 46, 1109-1136.

Ambar, I. and Howe, M.R., 1979. Observations of the Mediterranean outflow. II. The

Baringer, M.O., 1993. Mixing and Dynamics of the Mediterranean Outflow, PhD Thesis, Mass. Inst. of Technol./Woods Hole Oceanogr. Inst. Joint Program, Cambridge, Mass., WHOI-93-52, 244 pp.

Baringer, M.O. and Price, J.F., 1999. A review of the physical oceanography of the

Belderson, R.H., Johnson, M.A. and Kenyon, N., 1982. Bedforms. In: A.H. Stride (Ed), Offshore Tidal Sands: Processes and Deposits. Chapman and Hall, London, pp. 2757.

Berné, S., Castaing, P., Le Drezen, E. and Lericolais, G., 1993. Morphology, internal structure, and reversal of asymmetry of large subtidal dunes in the entrance to Gironde Estuary (France). Journal of sedimentary Petrology, 63, 780-793. 
474 Borenäs, K.M., Wahlin, A.K., Ambar, I. and Serra, N., 2002. The Mediterranean 475 outflow splitting--a comparison between theoretical models and CANIGO data. 476 Deep Sea Research Part II: Topical Studies in Oceanography, 49, 4195-4205.

477 Bower, A.S., Armi, L. and Ambar, I., 1997. Lagrangian observations of meddy 478 formation during a Mediterranean undercurrent seeding experiment. Journal of 479 Physical Oceanography, 27, 2545-2575.

480 Boyum, G., 1967. Hydrological observations of the M/S Helland-Hansen and current 481 measurements in the area west of Gibraltar, May 1965. NATO Sub-Comm.

483 Cirac, P., Berné, S., Castaing, P. and Weber, O., 1998. Processus de mise en place et 484 d'évolution de la couverture sédimentaire superficielle de la plate-forme nord485 aquitaine. Oceanologica Acta, 23, 663-686.

486 Cochonat, P. and Ollier, G., 1987. Interprétation géologique des images SAR. Données 487 de l'opération TITANIC, rapport scientifique et technique de l'Ifremer, 4, 66 pp.

488 Damuth, J.E., 1980. Use of high-frequency $(3.5-12 \mathrm{kHz})$ echograms in the study of 489 near-bottom sedimentation processes in the deep-sea: A review. Marine Geology, $490 \quad 38,51-75$.

491 Damuth, J.E. and Hayes, D.E., 1977. Echo character of the East Brazilian continental 492 margin and its relationship to sedimentary processes. Marine Geology, 24, 73-95.

493 Dyer, K.E., 1970. Linear erosional furrows in Southampton water. Nature, 225, 56-58.

494 Ehrhold, A., Guillou, S., Auffret, J.P., Garlan, T. and Dan Nguyen, K., 2003. Bedload 495 transport modelisation in a bay characterized by a macrotidal environment: example 496 of the Mont-Saint-Michel Bay (Manche, France). Oceanologica Acta, 26, 443-455.

497 Embley, R.W. and Hayes, D.E., 1976. New evidence for occurrence of debris flow 498 deposits in the deep sea. Geology, 4, 371-374. 
Farcy, A. and Voisset, M., 1985. Acoustic imagery of sea floor. In: V.C. Anderson (Ed),

$500 \quad$ Oceans `85: Ocean Engineering and the Environment, New York (IEEE), pp. 1005-

$501 \quad 1012$.

502 Faugères, J.-C., Cremer, M., Monteiro, J.H. and Gaspar, L., 1985a. Essai de 503 reconstitution des processus d'édification de la ride sédimentaire de Faro (marge 504 sud-portugaise). Bulletin de l'Institut de Géologie du Bassin d'Aquitaine, 37, 229505258.

506 Faugères, J.-C., Frappa, M., Gonthier, E. and Grousset, F.E., 1985b. Impact de la veine 507

510 Faugères, J.-C., Stow, D.A.V., Imbert, P. and Viana, A., 1999. Seismic features 511 diagnostic of contourite drifts. Marine Geology, 162, 1-38.

512 Flemming, B.W., 1979. Sand transport and bedform patterns on the continental shelf 513 between Durban and Port Elizabeth (southeast African continental margin). 514 Sedimentary Geology, 26, 179-205.

515 García, M., 2002. Caracterización morfológica del sistema de canales y valles 516 submarinos del talud medio del Golfo de Cádiz (SO de la Península Iberica): 517 implicaciones oceanográficas, Tesis de Licenciatura, Facultad de Ciencas del Mar, 518 Univ. Cádiz, 114 pp.

519 Gardner, J.V. and Kidd, R.B., 1983. Sedimentary processes on the Iberian continental 520 margin viewed by long-range side-scan sonar. 1: Gulf of Cadiz. Oceanologica Acta, $521 \quad 6,245-254$.

522 Gonthier, E., Faugères, J.-C. and Stow, D.A.V., 1984. Contourite facies of the Faro 523 drift, Gulf of Cadiz. In: D.A.V. Stow and D.J.W. Piper (Eds), Fine-Grained 

Scientific Publications, Oxford London Edinburg, pp. 245 -256.

526 Habgood, E.L., Kenyon, N.H., Masson, D.G., Akhmetzhanov, A., Weaver, P.P.E., Gardner, J.M. and Mulder, T., 2003. Deep-water sediment wave fields, bottom current sand channels and gravity flow channel-lobe systems: Gulf of Cadiz, NE Atlantic. Sedimentology, 50, 483-510.

530 Hanquiez, V., Mulder, T., Lecroart, P., Voisset, M., Gonthier, E., Marches, E. and Girardi, A. Chirp echo characters of the surficial sediments in the eastern Gulf of Cadiz (NE Atlantic). Geo-Marine Letters, accepted.

Heezen, B.C., Hollister, C.D. and Ruddiman, W.F., 1966. Shaping of the continental rise by deep geostrophic contour currents. Science, 152, 502-508.

Heezen, B.C. and Johnson, G.L., 1969. Mediterranean under-current and microphysiography west of Gibraltar. Bulletins de l'Institut Oceanographique de Monaco, 67, 1-97.

Hernández-Molina, F.J., Llave, E., Somoza, L., Fernandez-Puga, M.C., Maestro, A., León, R., Medialdea, T., Barnolas, A., Garcia, M., Díaz-del-Río, V., FernandezSalas, L.M., Vázquez, J.T., Lobo, F.J., Alveirinho Dias, J.M., Rodero, J. and Gardner, J.M., 2003. Loocking for clues to paleoceanographic imprits: A diagnosis of the Gulf of Cadiz contourite depositional systems. Geology, 31, 19-22.

Hernández-Molina, F.J., Llave, E., Stow, D.A.V., Garcia, M., Somoza, L., Vazquez, J.T., Lobo, F.J., Maestro, A., Diaz del Rio, V. and Leon, R., 2006. The contourite depositional system of the Gulf of Cadiz: A sedimentary model related to the bottom current activity of the Mediterranean outflow water and its interaction with the continental margin. Deep Sea Research Part II: Topical Studies in Oceanography, 53, 1420-1463. 
549 Hollister, C.D., Flood, R.D., Johnson, D.A., Lonsdale, P. and Southard, J.B., 1974. 550 Abyssal furrows and hyperbolic echo traces on the Bahama Outer Ridge. Geology, $2,395-400$.

Jacobi, R.D., 1976. Sediment slides on the northwestern continental margin of Africa. Marine Geology, 22, 157-173.

Johnson, J., Ambar, I., Serra, N. and Stevens, I., 2002. Comparative studies of the spreading of Mediterranean water through the Gulf of Cadiz. Deep Sea Research Part II: Topical Studies in Oceanography, 49, 4179-4193.

Johnson, J. and Stevens, I., 2000. A fine resolution model of the eastern North Atlantic between the Azores, the Canary Islands and the Gibraltar Strait. Deep-Sea Research Part I: Oceanographic Research Papers, 47, 875-899.

Kenyon, N.H. and Belderson, R.H., 1973. Bed forms of the Mediterranean undercurrent observed with side-scan sonar. Sedimentary Geology, 9, 77-99.

Llave, E., Hernández-Molina, F.J., Somoza, L., Díaz-del-Río, V., Stow, D.A.V., Maestro, A. and Dias, J.M.A., 2001. Seismic stacking pattern of the Faro-Albufeira contourite system (Gulf of Cadiz): a Quaternary record of paleoceanographic and tectonic influences. Marine Geophysical Researches, 22, 487-508.

566 Llave, E., Hernández-Molina, F.J., Somoza, L., Stow, D.A.V. and Diaz del Rio, V., 2007. Quaternary evolution of the Contourite Depositional System in the Gulf of Cadiz. In: A. Viana and M. Rebesco (Eds), Economic and Paleoceanographic Importance of Contourites. Geological Society of London, Special Publication, pp. 49-80.

Llave, E., Schönfeld, J., Hernandez-Molina, F.J., Mulder, T., Somoza, L., Diaz del Rio, V. and Sanchez-Almazo, I., 2006. High-resolution stratigraphy of the Mediterranean outflow contourite system in the Gulf of Cadiz during the late Pleistocene: The impact of Heinrich events. Marine Geology, 227, 241-262. 
575

576

577

578

579

580

581

582

583

584

585

586

587

588

589

590

591

592

593

594

595

596

597

598

599

Lopez-Galindo, A., Rodero, J. and Maldonado, A., 1999. Surface facies and sediment dispersal patterns: southeastern Gulf of Cadiz, Spanish continental margin. Marine Geology, 155, 83-98.

Madelain, F., 1970. Influence de la topographie du fond sur l'écoulement méditerranéen entre le détroit de Gibraltar et le cap Saint-Vincent. Cahiers Océanographiques, 22, $43-61$.

Maldonado, A. and Nelson, C.H., 1999. Interaction of tectonic and depositional processes that control the evolution of the Iberian Gulf of Cadiz margin. Marine Geology, 155, 217-242.

McCave, I.N., 1984. Erosion, transport and deposition of fine-grained marine sediments. In: D.A.V. Stow and D.J.W. Piper (Eds), Fine-Grained Sediments: Deep Water Processes and Facies. The Geological Society of London, Special Publication, pp. 35-69.

Meincke, J., Siedler, G. and Zenk, W., 1975. Some current observations near the continental slope off Portugal. "Meteor"Forsch.-Ergebnisse, 16, 15-22.

Mélières, F., 1974. Recherches sur la dynamique sédimentaire du Golfe de Cadix (Espagne), Thèse d'Etat de l'Université Pierre et Marie Curie, Paris, 235 pp.

Migeon, S., 2000. Dunes géantes et levées sédimentaires en domaine marin profond: approche morphologique, sismique et sédimentologique, Thèse de 3ème cycle, Université Bordeaux 1, Talence.

Mulder, T., Voisset, M., Lecroart, P., Le Drezen, E., Gonthier, E., Hanquiez, V., Faugères, J.-C., Habgood, E.L., Hernández-Molina, F.J., Estrada, F., LlaveBarranco, E., Poirier, D., Gorini, C., Fuchey, Y., Voelker, A., Freitas, P., Lobo Sanchez, F.J., Fernandez, L.M., Kenyon, N.H. and Morel, J., 2003. The Gulf of Cadiz: an unstable giant contouritc levee. Geo-Marine Letters, 23, 7-18. 
600 Nelson, C.H., Baraza, J. and Maldonado, A., 1993. Mediterranean undercurrent sandy

601 contourites, Gulf of Cadiz, Spain. Sedimentary Geology, 82, 103 -131.

602 Nelson, C.H., Baraza, J., Maldonado, A., Rodero, J., Escutia, C. and Barber, J.H., 1999.

603 Influence of the Atlantic inflow and Mediterranean outflow currents on Late

604 Quaternary sedimentary facies of the Gulf of Cadiz continental margin. Marine

605 Geology, 155, 99-129.

606 Normark, W.R., 1978. Fan valleys, channels, and depositional lobes on modern

607 submarine fans : Characters for recognition of sandy turbidite environments.

608 Bulletin of the American Association of Petroleum Geologists, 62, 912-931.

609 Normark, W.R., Posamentier, H. and Mutti, E., 1993. Turbidite systems: State of the art 610 and future directions. Reviews of Geophysics, 31, 91-116.

611 Ochoa, J. and Bray, N.A., 1991. Water mass exchange in the Gulf of Cadiz. Deep Sea $612 \quad$ Research, 38, 5465-5503.

613 Prather, B.E., 2000. Calibration and visualization of depositional process models for 614 above-grade slopes: a case study from the Gulf of Mexico. Marine and Petroleum $615 \quad$ Geology, 17, 619-638.

616 Sartori, R., Torelli, L., Zitellini, N., Peis, D. and Lodolo, E., 1994. Eastern segment of 617 the Azores-Gibraltar line (central-eastern Atlantic): An oceanic plate boundary with 618 diffuse compressional deformation. Geology, 22, 555-558.

619 Simons, D.B. and Richardson, E.V., 1961. Forms of bed roughness in alluvial channels. 620 Journal of the Hydraulics Div., ASCE, 87(HY3), 87-105.

621 Srivastava, S.P., Shouten, H., Roest, W.R., Klitgord, K.D., Kovacs, L.C., Verhoef, J. 622 and Macnab, R., 1990. Iberian plate kinematics: a jumping plate boundary between 623 Eurasia and Africa. Nature, 344, 756-759.

624 Sternberg, R.W., 1968. Frictions factors in tidal channels with differing bed roughness. 625 Marine Geology, 6, 242-260. 
626 Stow, D.A.V., Faugères, J.-C. and Gonthier, E., 1986. Facies distribution and textural 627 variation in Faro Drift contourites : velocity fluctuation and drift growth. Marine $628 \quad$ Geology, 72, 71-100.

629 Stow, D.A.V., Faugères, J.-C., Gonthier, E., Cremer, M., Llave, E., Hernández-Molina, 630 F.J., Somoza, L. and Díaz-del-Río, V., 2002. Faro-Albufeira drift complex, northern 631 Gulf of Cadiz. In: D.A.V. Stow, C.J. Pudsey, J.A. Howe, J.-C. Faugères and A.R. 632 Viana (Eds), Deep-water contourite systems: modern drifts and ancient series, 633 seismic and sedimentary characteristics. Geological Society of London, London, $634 \quad$ UK, pp. 137-154.

635 Turcq, B., 1984. Les faciès sédimentaires du plateau continental nord-aquitain : réponse 636 aux processus hydrodynamiques actuels, Thèse de 3ème cycle, Université Bordeaux $637 \quad 1$.

638 Walker, R.G., 1978. Deep-water sandstone facies and ancient submarine fans: model for 639 exploration for stratigraphic traps. Bulletin of the American Association of $640 \quad$ Petroleum Geologists, 62, 932-966.

641 Zenk, W., 1975. On the Mediterranean outflow west of Gibraltar. "Meteor"Forsch.642 Ergebnisse, 16, 23-34.

643 Zenk, W. and Armi, L., 1990. The complex spreading patterns of Mediterranean water 644 off the Portuguese continental slope. Deep Sea Research, 37, 1805-1823.

645

646 FIGURE LEGENDS

647 Figure 1. Map of the Gulf of Cadiz showing the general MOW pathway (grey area); 648 black dotted arrows indicate MOW direction; black arrows indicate Atlantic Inflow 649 direction; IMB: Intermediate MOW Branch; MLW: Mediterranean Lower Water; 650 MUW: Mediterranean Upper Water; MMB: Main MOW Branch; PMB: Principal 
651 MOW Branch; SMB: Southern MOW Branch. Modified from Madelain (1970) and

652 Hernández-Molina et al. (2003).

653 Figure 2. High resolution EM300 illuminated color-shaded map of the studied area 654 during the CADISAR cruise. BDD: Bartolome Dias Drift; CC: Cadiz Contourite 655 Channel; CL: Giant Contouritic Levee; CR: Cadiz Ridge; c1 to c4: constriction points; 656 DR: Doñana Ridge; FCD: Faro-Cadiz Drift; GB: Guadalquivir Bank; GC: Guadalquivir 657 Contourite Channel; GD: Guadalquivir Drift; GEC: Gil Eanes Channel; GR: 658 Guadalquivir Ridge; HC: Huelva Channel; HD: Huelva Drift; MMC: Main MOW 659 Channel; PB: ponded basins; SC: secondary channels; t: trench. Numbers 1, 2 and 3 are 660 morpho-sedimentary sectors defined by Hernández-Molina et al. (2003); 1: proximal 661 scour and sand-ribbons sector; 2: channels and ridges sector; 3: overflow-sedimentary 662 lobe sector.

663 Figure 3. High resolution EM300 and SAR acoustic imagery map of the area studied 664 during the CADISAR cruise. Red numbers are core location. Boxes are SAR image 665 location.

666 Figure 4. Sedimentary facies distribution in the eastern part of the Gulf of Cadiz based 667 on the acoustic imagery interpretation.

668 Figure 5. SAR images and interpretations showing erosive and deposit bedforms on the 669 Main MOW Channel (see location in Figure 3). White arrows are current directions.

670 Figure 6. SAR images and interpretations illustrating the bend and the erosive nature of 671 the SMB in the Cadiz Channel (see location in Figure 3). White arrows are current 672 directions.

673 Figure 7. SAR images and interpretations displaying the lateral facies variation across 674 the downstream part of the Cadiz Channel and the progressive northwestward bend of 675 the SMB (see location in Figure 3). White arrows are current directions. 
676 Figure 8. SAR image and interpretation showing the slightly erosive nature of the PMB

677 along the central part of the Guadalquivir Channel (see location in Figure 3). White 678 arrow is current direction.

679 Figure 9. SAR images and interpretations showing instabilities on the Giant Contouritic 680 Levee on the western bank of the Main MOW Channel (see location in Figure 3). White 681 arrows are current directions.

682 Figure 10. SAR image and interpretation illustrating the bedform variability across the 683 Gil Eanes Channel (see location in Figure 3). White arrow is current direction.

684 Figure 11. SAR imageries and interpretations of the bedforms identified along the 685 secondary channels connected to the Main MOW Channel (see location in Figure 3). 686 White arrows are current directions.

687 Figure 12. Semi quantitative hydrodynamic model in the eastern part of the Gulf of 688 Cadiz. Black, white and red arrows are MOW directions. Yellow arrows are gravity 689 current directions. Black and white arrows respectively represent minimal and maximal 690 transport velocities $(U)$. Vector direction is deduced from bedform orientations.

691

692 TABLES

693 Table 1. Major grain-size classes of surficial sediments and Shearing $\left(U^{*}\right)$ and transport $694(U)$ velocities calculated from the Sternberg (1968) and McCave (1984) methods (core 695 location in Figure 3).

696 Table 2. Sedimentary facies classification based on EM300, SAR, chirp and core data. 


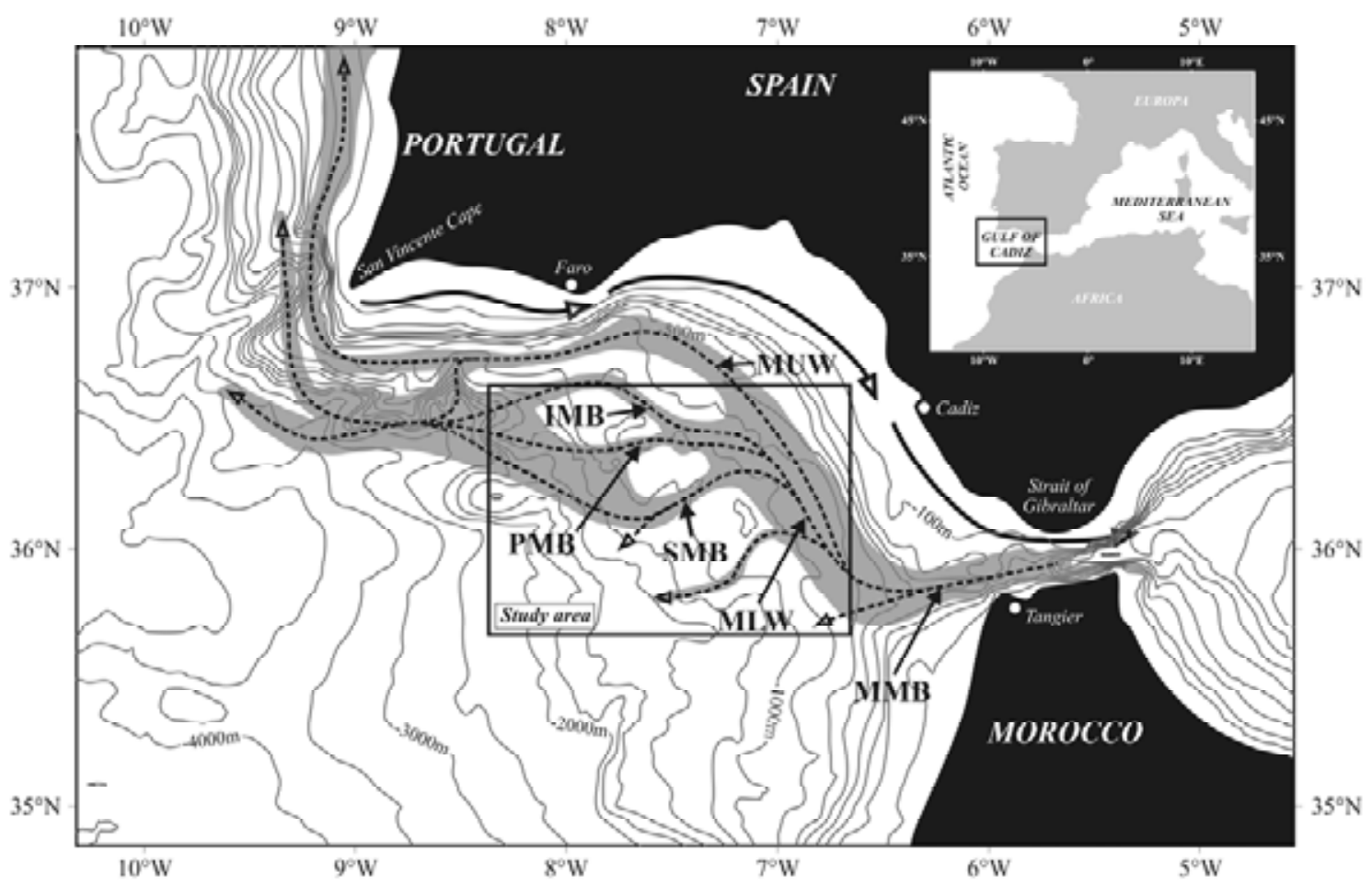

Figure 1 


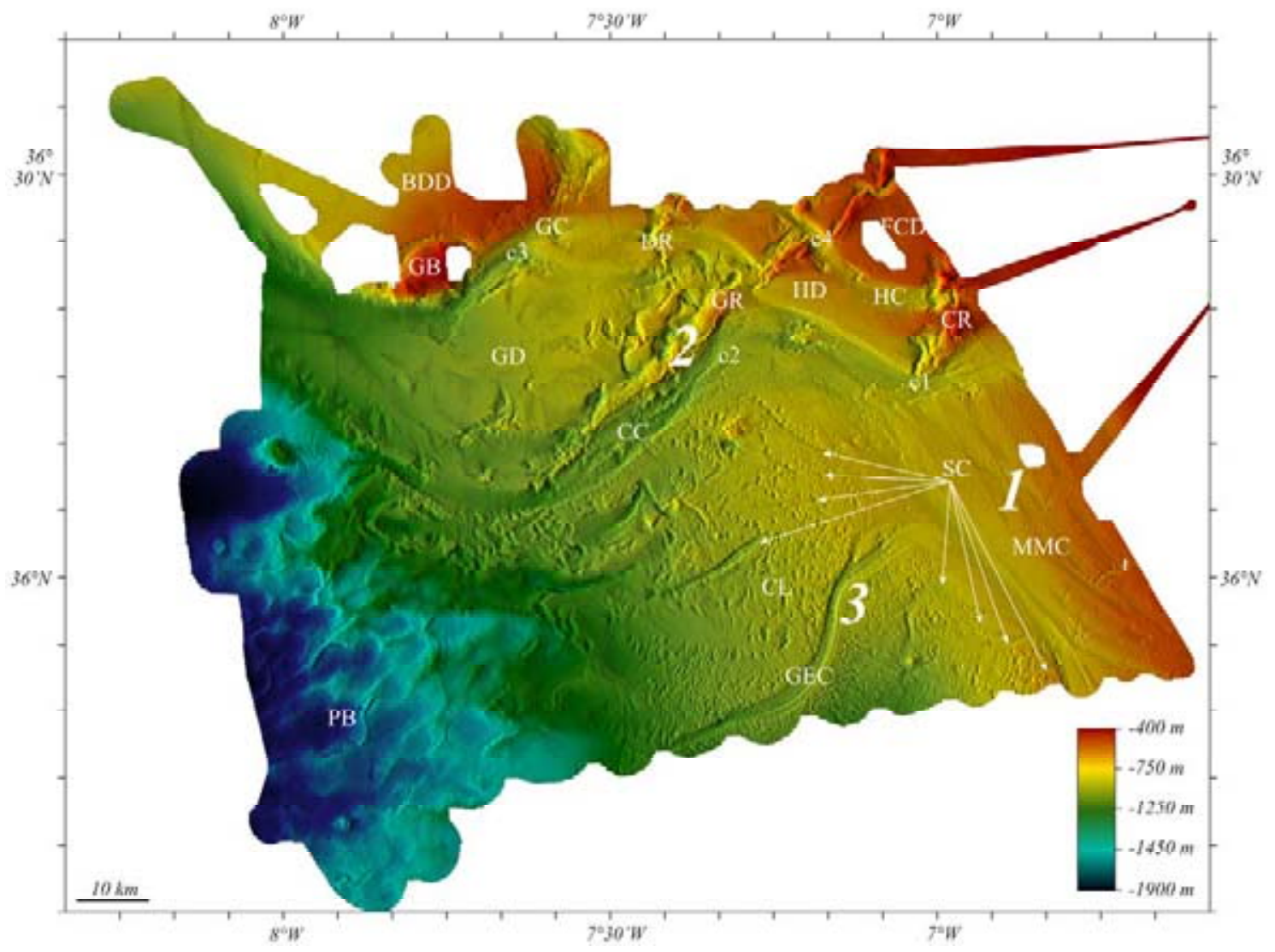

Figure 2 


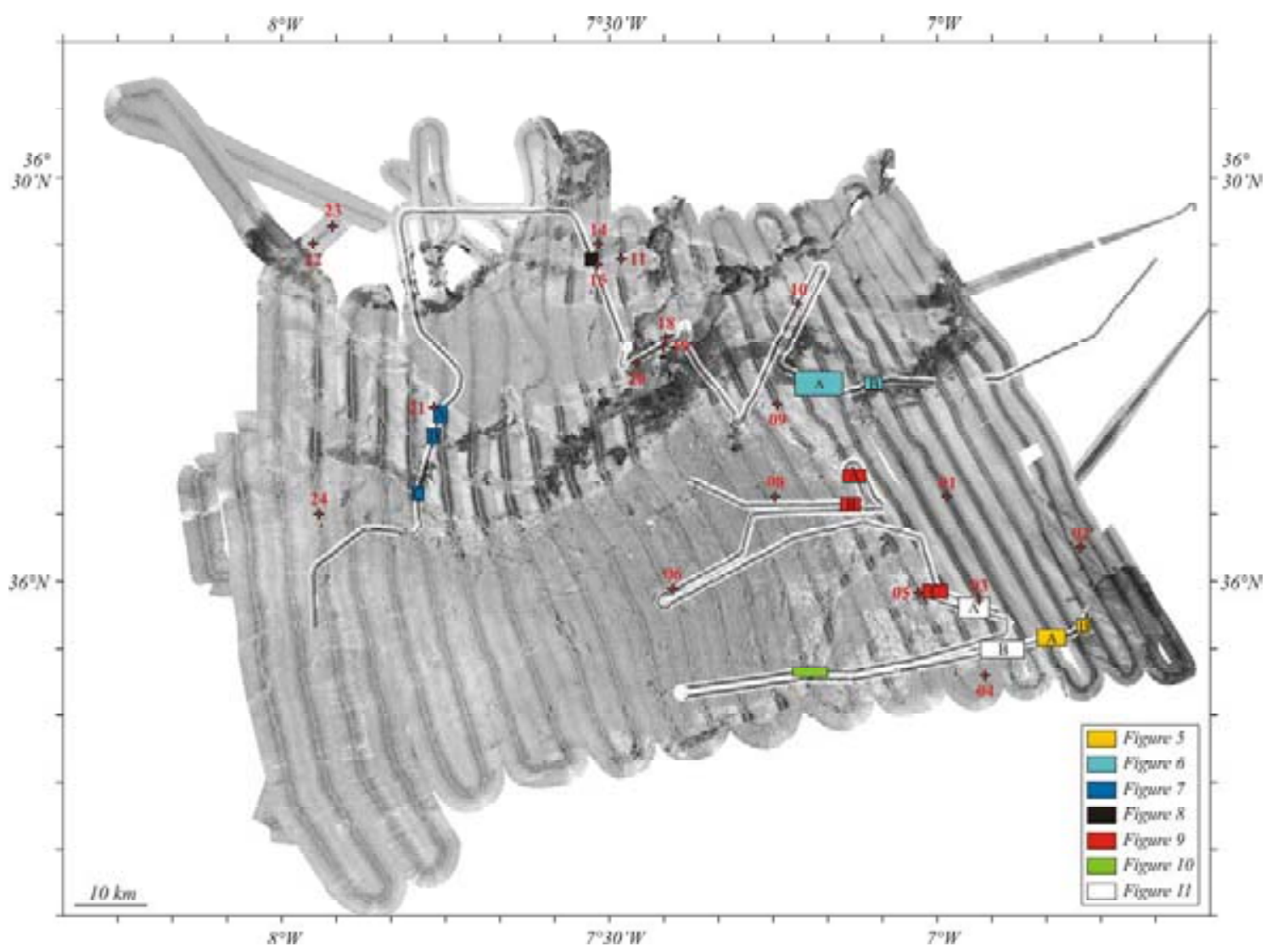

Figure 3 


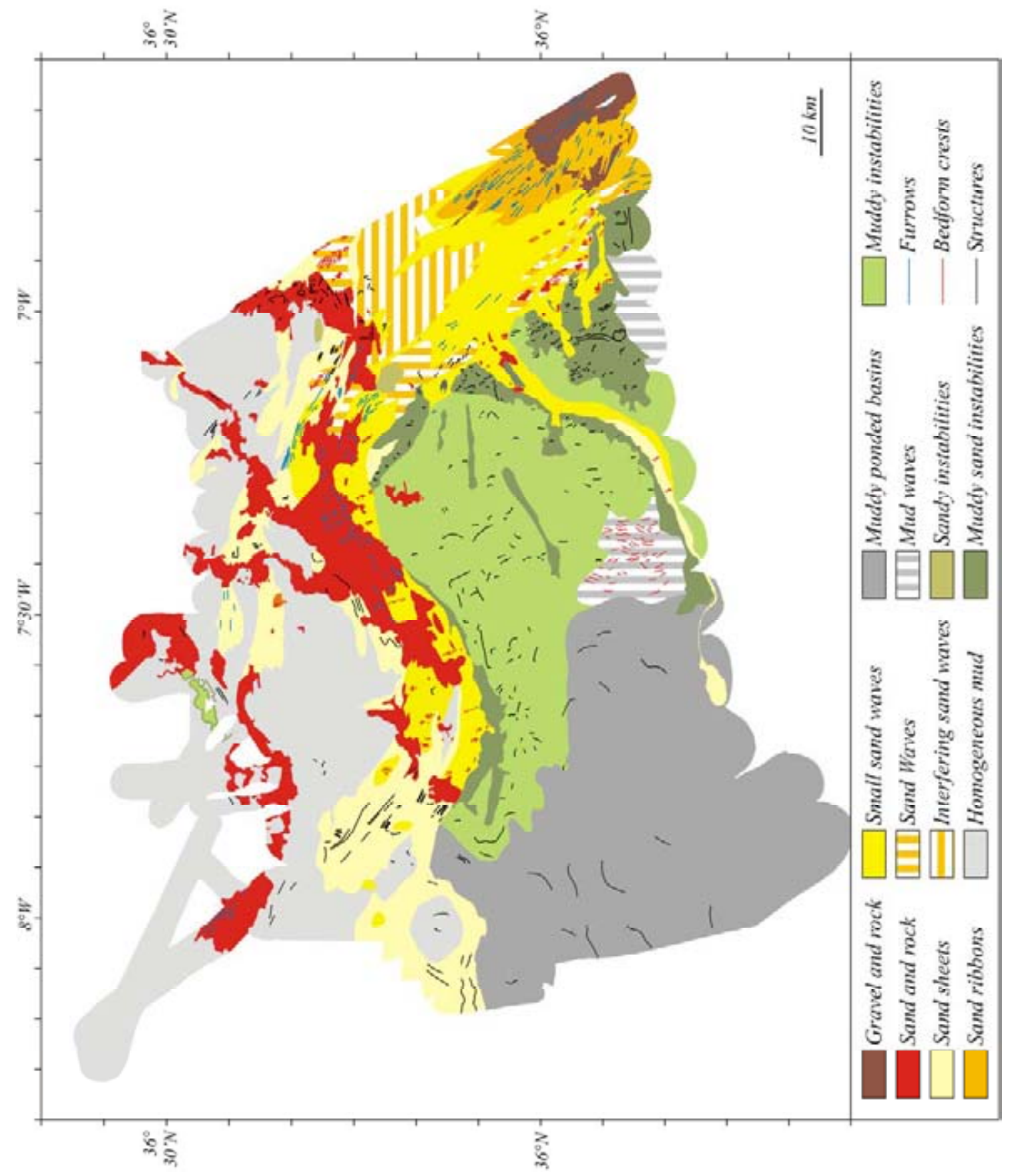

Figure 4 

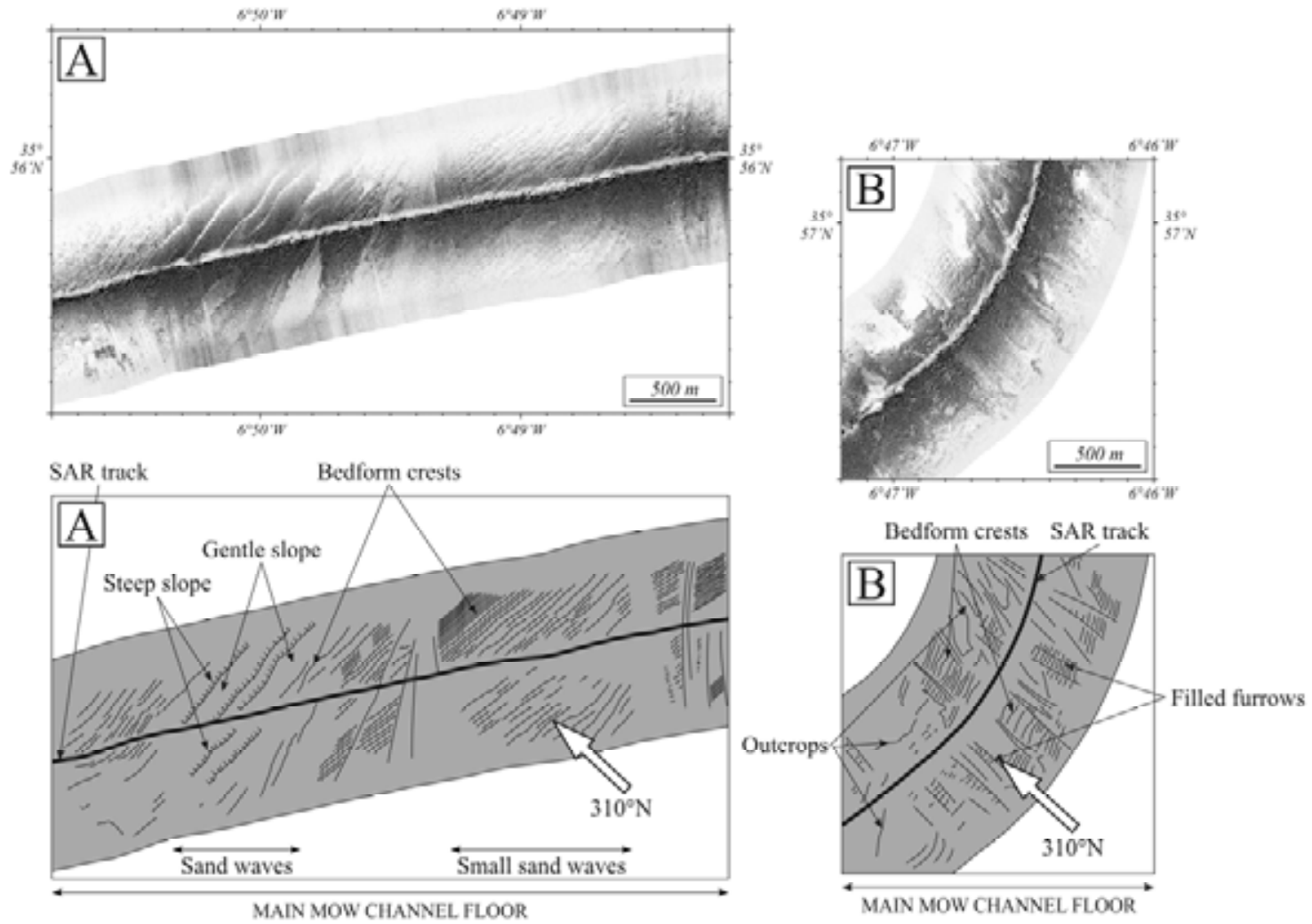

Figure 5 

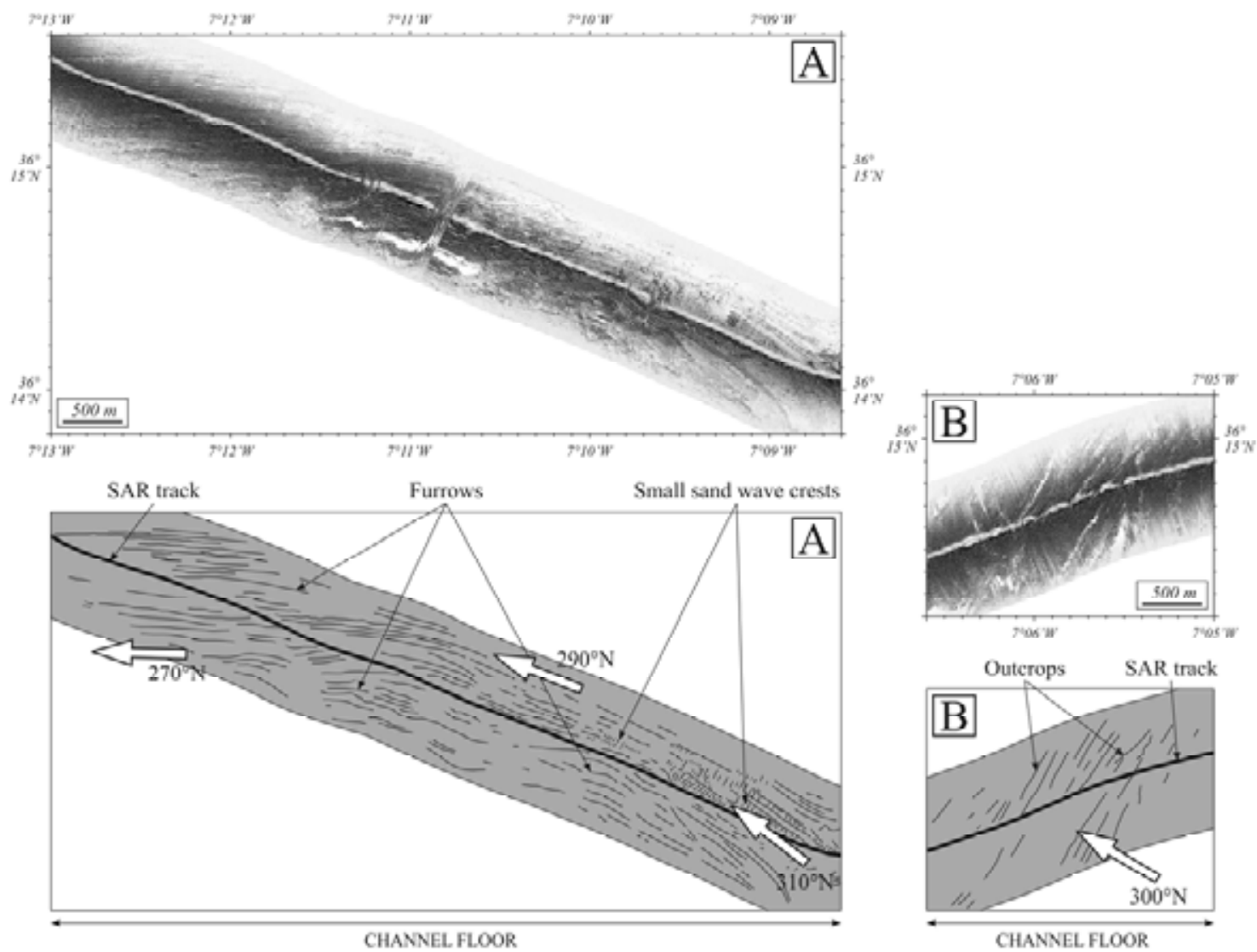

Figure 6 

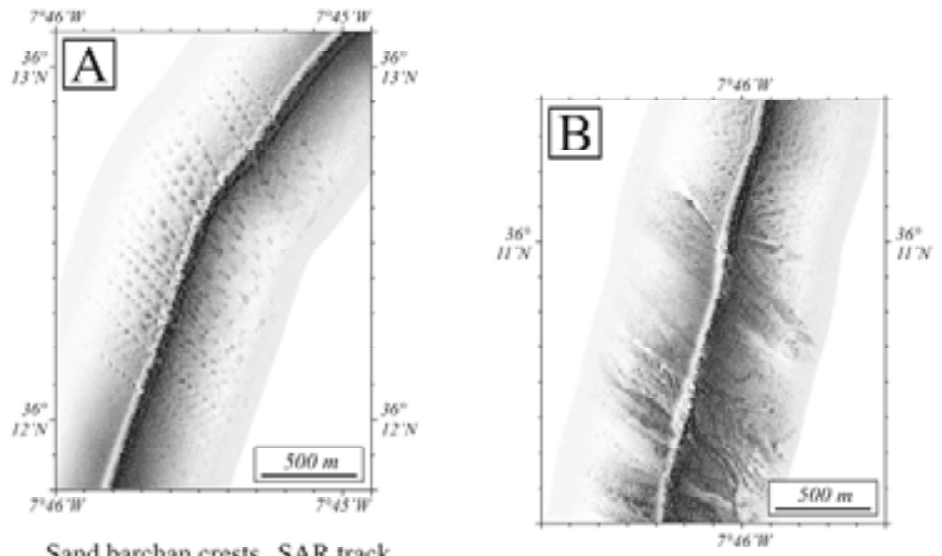

Sand barchan crests SAR track

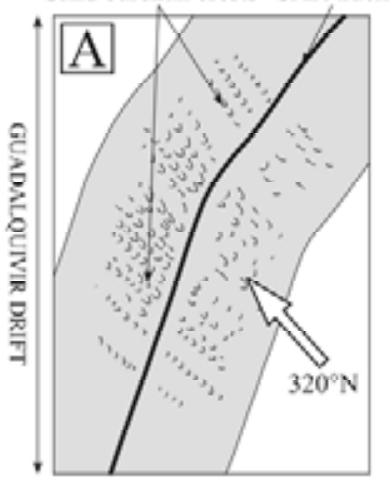

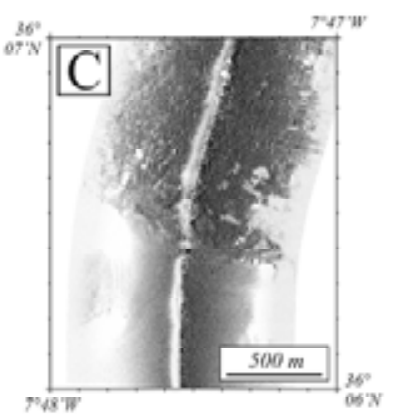
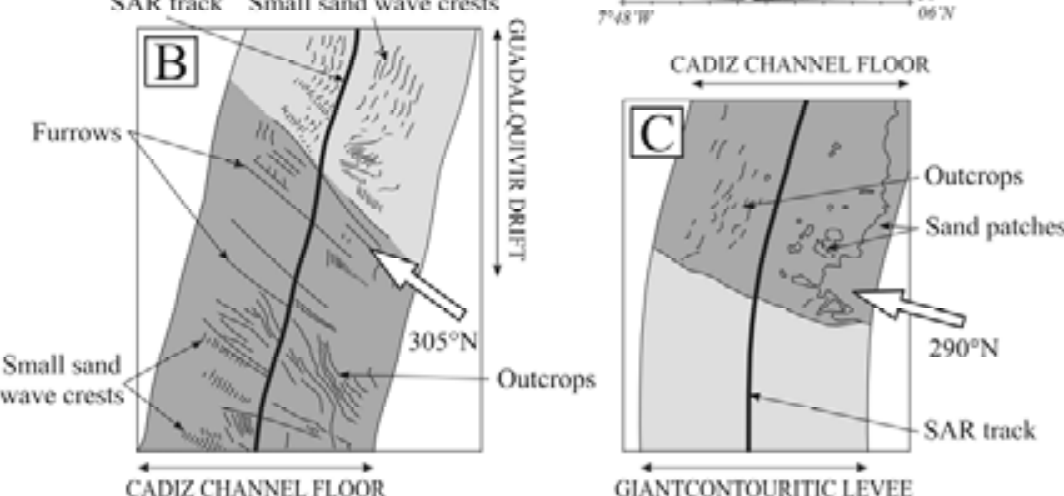

Figure 7 

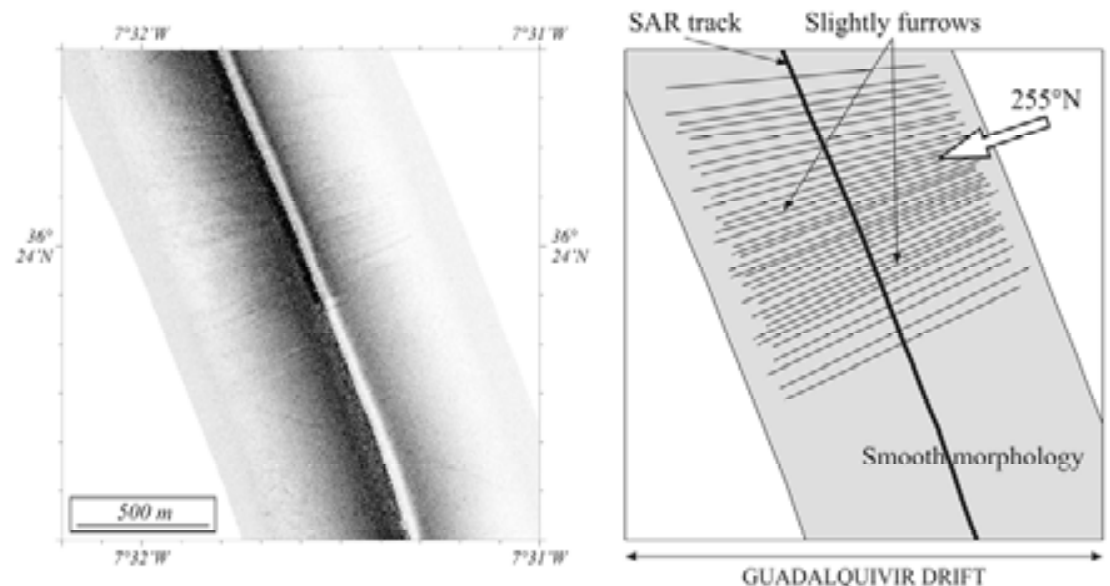

Figure 8 

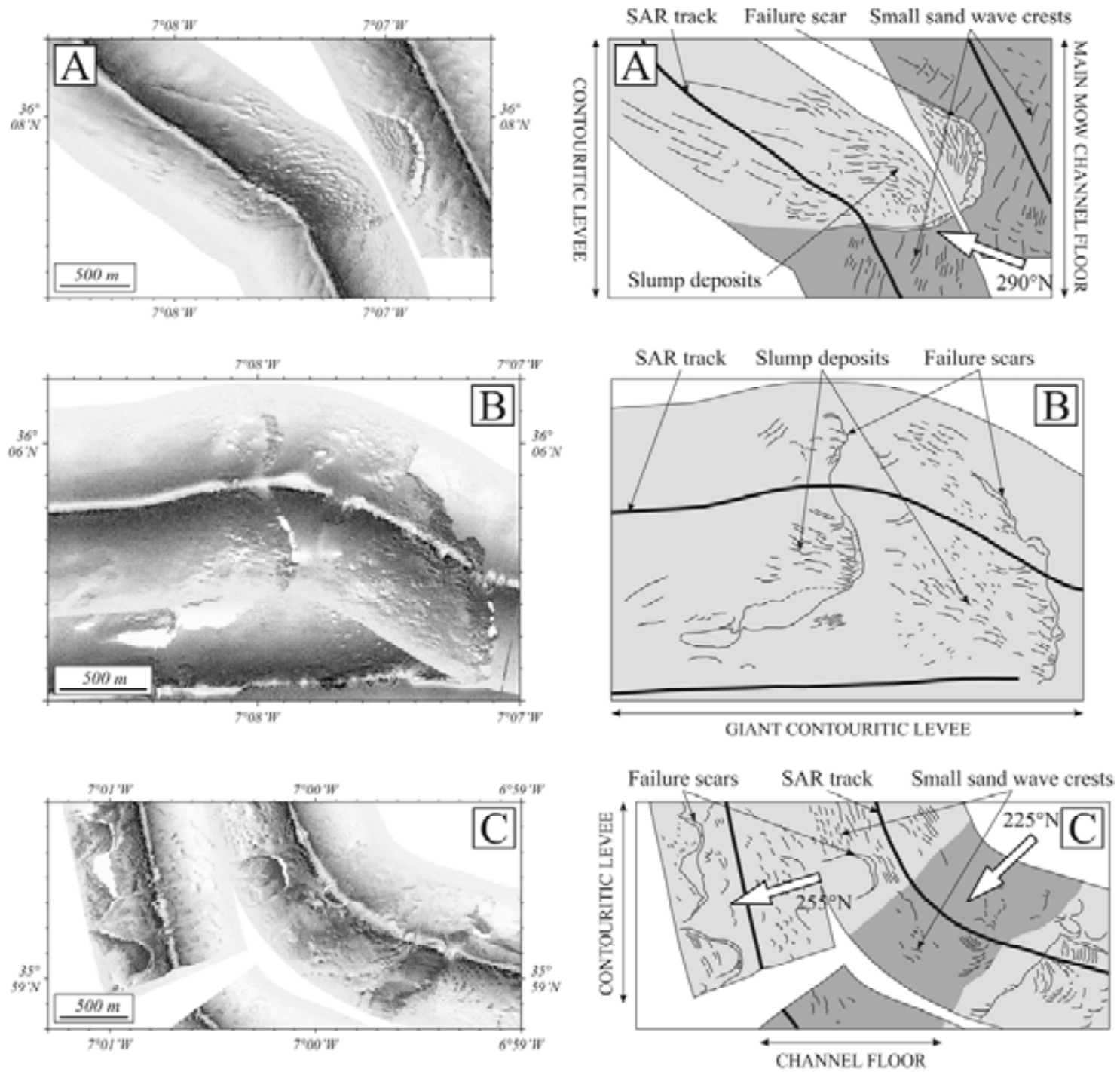

Figure 9 

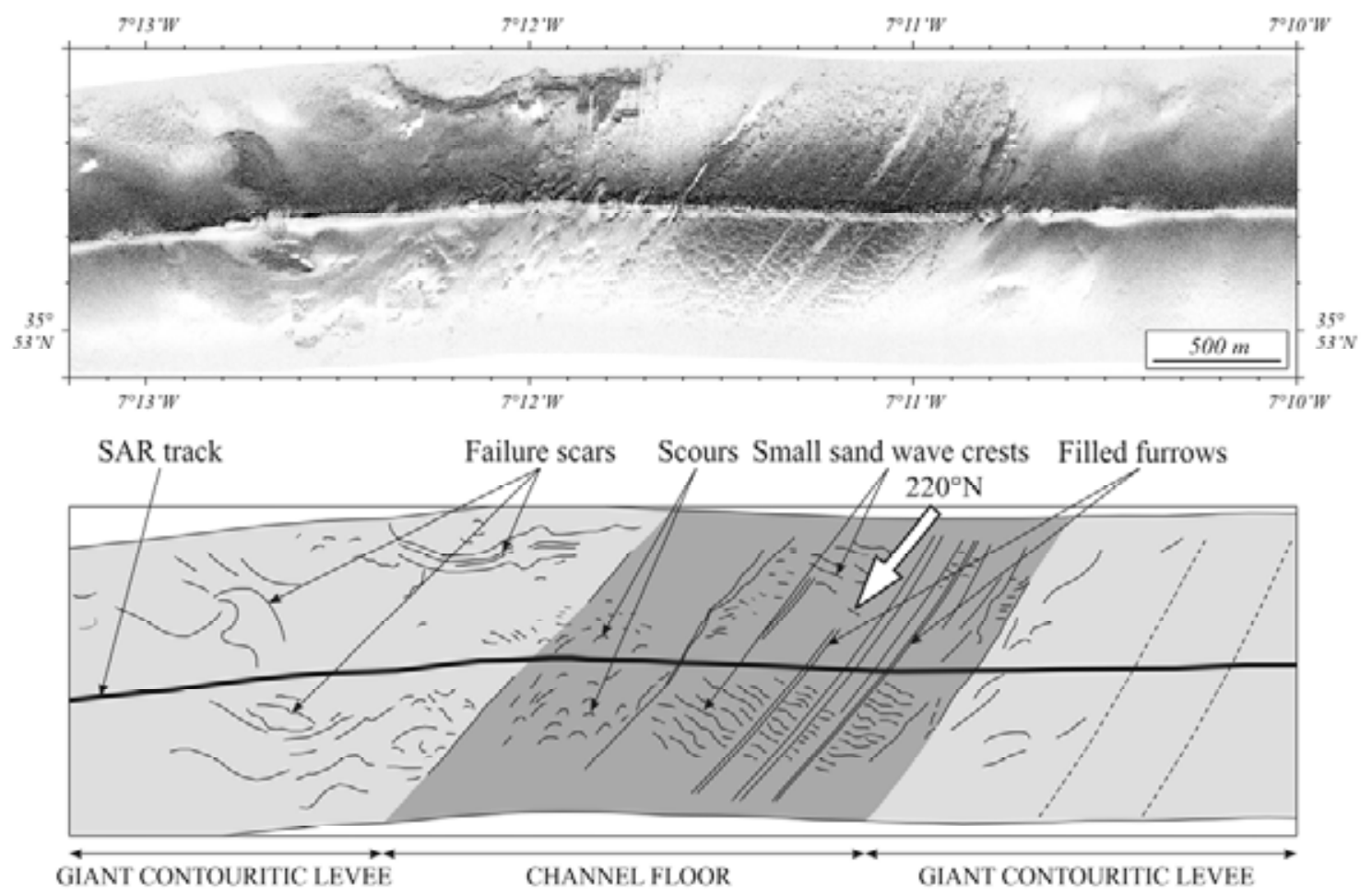

Figure 10 

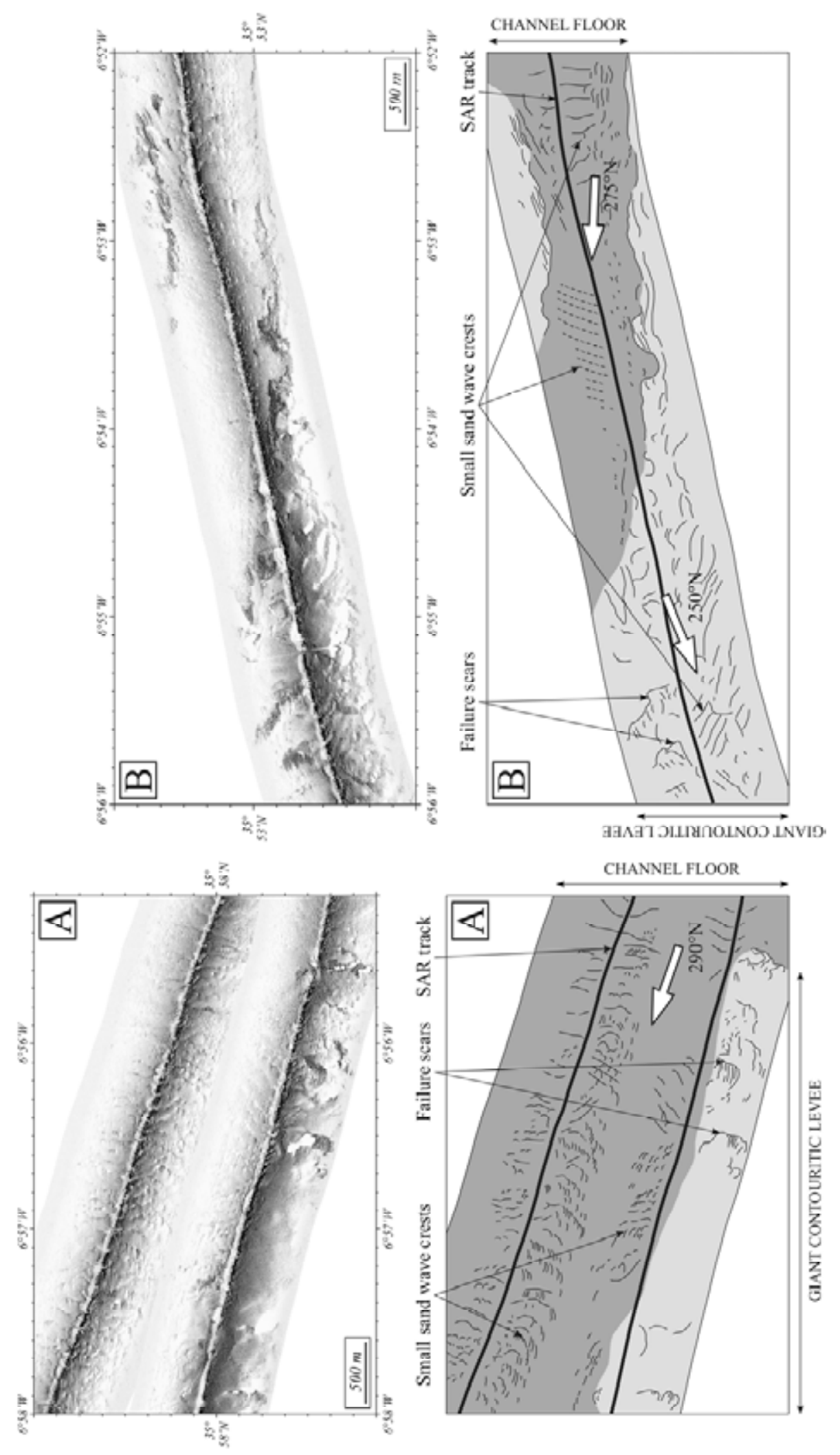

Figure 11 


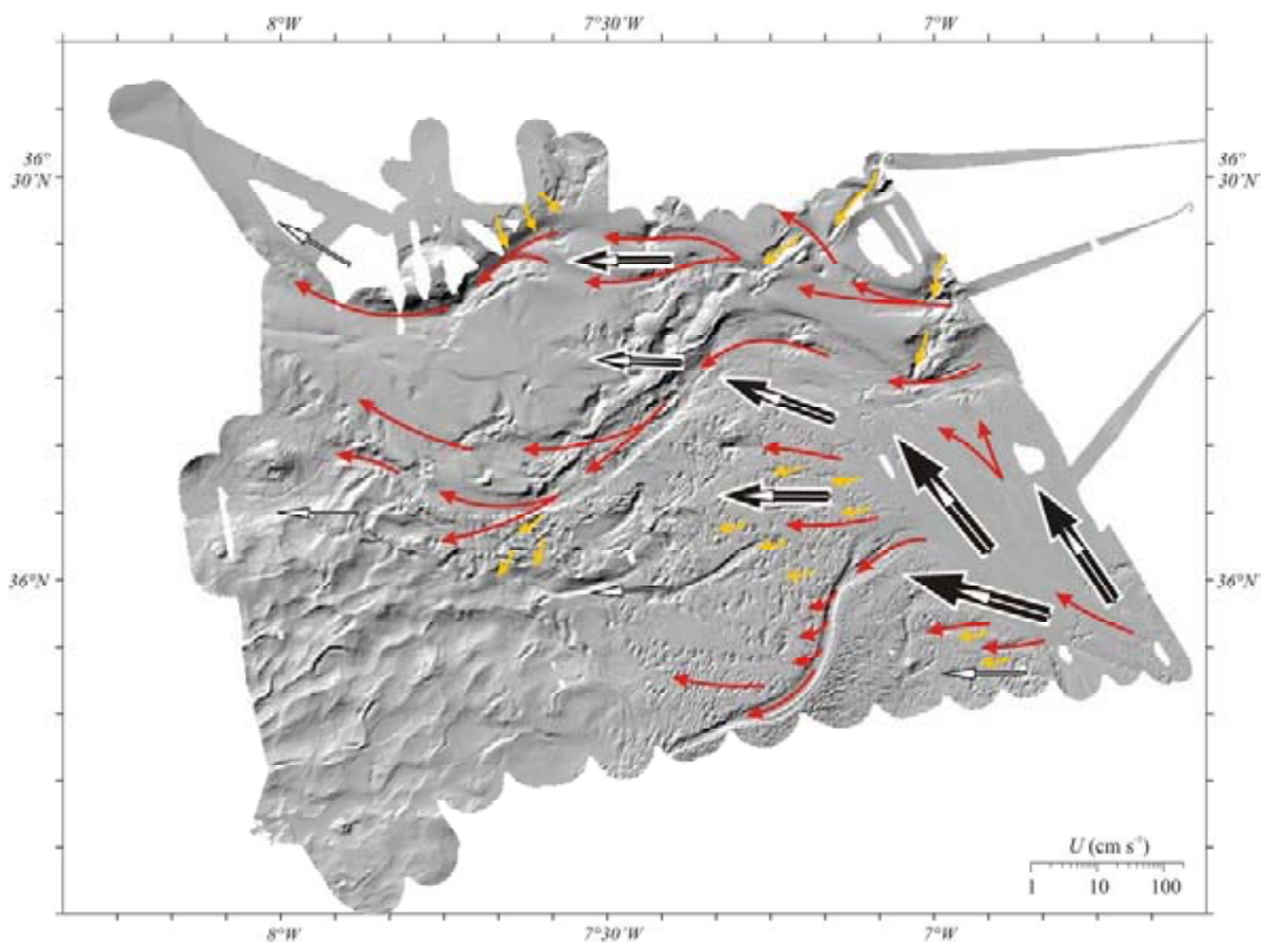

Figure 12 


\begin{tabular}{|c|c|c|c|c|c|c|c|c|}
\hline \multirow[b]{2}{*}{ Core } & \multicolumn{3}{|c|}{ Granulometric classes $(\%)$} & \multirow[b]{2}{*}{$\mathrm{D} 90(\mu \mathrm{m})$} & \multicolumn{2}{|c|}{$U^{x}\left(\mathrm{~cm} \mathrm{~s}^{-1}\right)$} & \multicolumn{2}{|c|}{$U\left(\mathrm{~cm} \mathrm{~s}^{-1}\right)$} \\
\hline & $\overline{C l a y}(<10 \mu \mathrm{m})$ & Silt $(10-63 \mu \mathrm{m})$ & Sand $(>63 \mu \mathrm{m})$ & & Min. & Max. & $\overline{\text { Min. }}$ & Max. \\
\hline$\overline{\text { CADKS01 }}$ & 4 & 9 & 87 & 627 & 1.80 & 10.5 & 32.0 & 190 \\
\hline CADKS02 & 3 & 8 & 89 & 395 & 1.60 & 6.50 & 28.0 & 115 \\
\hline CADKS03 & 2 & 3 & 95 & 659 & 1.90 & 11.0 & 34.0 & 200 \\
\hline CADKS04 & 31 & 59 & 11 & 64 & 0.95 & undefined $*$ & 17.0 & undefined $*$ \\
\hline CADKS05 & 34 & 61 & 5 & 46 & 0.85 & undefined $*$ & 15.0 & undefined $*$ \\
\hline CADKS06 & 35 & 61 & 3 & 38 & 0.80 & undefined $*$ & 14.0 & undefined $*$ \\
\hline CADKS08 & 6 & 17 & 77 & 211 & 1.30 & 2.80 & 23.0 & 50.0 \\
\hline CADKS09 & 8 & 23 & 69 & 271 & 1.40 & 4.00 & 25.0 & 70.0 \\
\hline CADKS11 & 9 & 33 & 58 & 191 & 1.20 & 2.00 & 21.0 & 36.0 \\
\hline CADKS14 & 30 & 53 & 17 & 101 & 1.00 & undefined $*$ & 18.0 & undefined $*$ \\
\hline CADKS15 & 6 & 25 & 69 & 150 & 1.10 & 1.50 & 20.0 & 27.0 \\
\hline CADKS18 & 20 & 39 & 41 & 189 & 1.20 & 2.00 & 21.0 & 36.0 \\
\hline CADKS 19 & 16 & 34 & 50 & 550 & 1.70 & 9.50 & 30.0 & 170 \\
\hline CADKS20 & 23 & 57 & 20 & 136 & 1.10 & 1.30 & 20.0 & 23.0 \\
\hline CADKS22 & 39 & 52 & 9 & 57 & 0.90 & undefined $*$ & 16.0 & undefined $^{*}$ \\
\hline CADKS23 & 31 & 63 & 6 & 44 & 0.85 & undefined $^{*}$ & 15.0 & undefined $^{*}$ \\
\hline CADKS24 & 37 & 62 & 2 & 33 & 0.80 & undefined $*$ & 14.0 & undefined $*$ \\
\hline
\end{tabular}

* Fine-grained particles (D90<100 $\mu \mathrm{m})$ are only transported as suspended load.

Table 1 


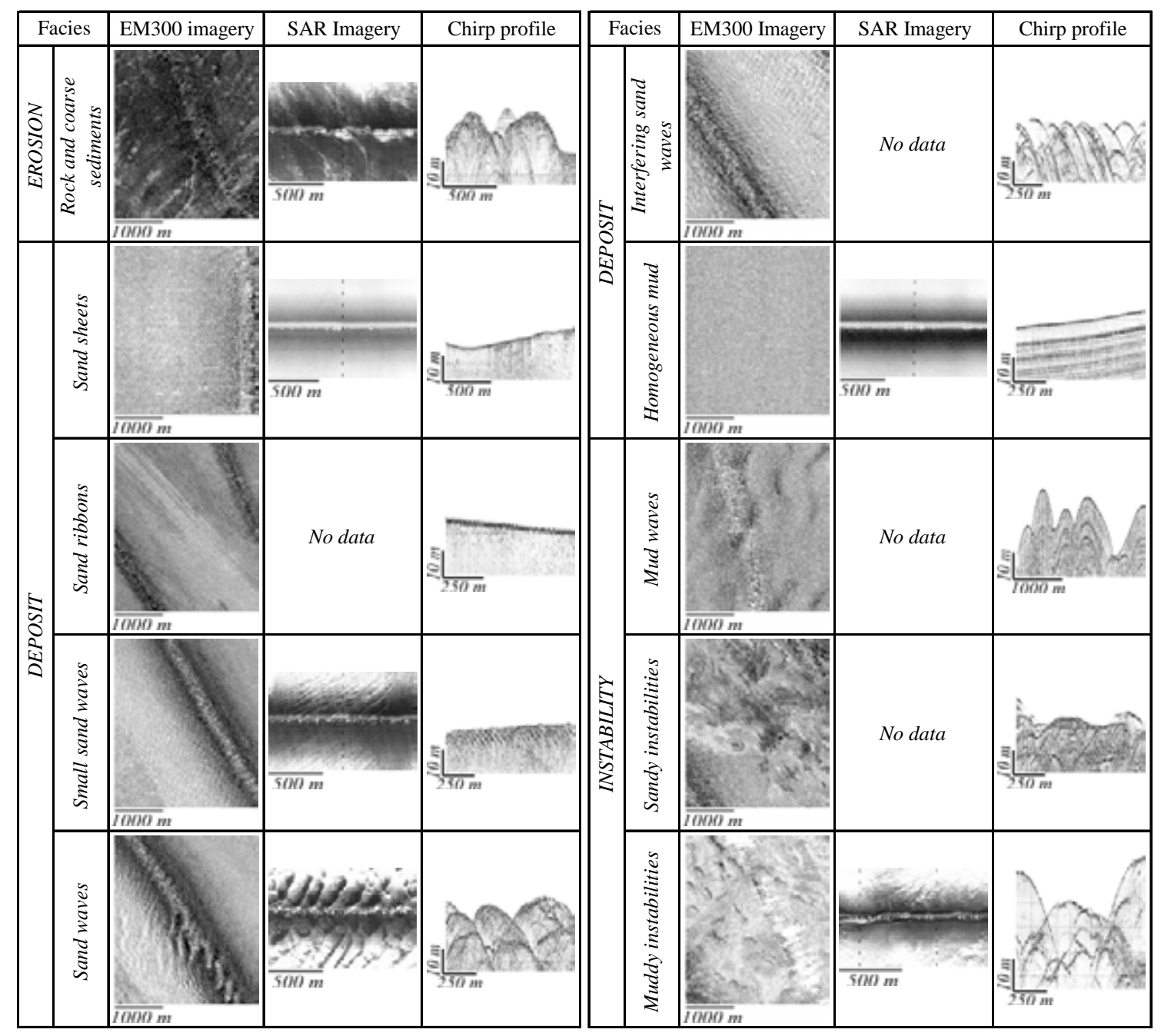

Table 2 